\title{
The Experience of Living With an Absent Child
}

Maureen Connolly

University of Alberta

His name is Phillip Thomas. I had to walk him down here. Please could you take him to the hospital where he can get proper care and live in a clean environment. I would take him but I cannot afford it. From there maybe you could see that he gets to an adoption agency. I love him with all my heart-enough to sacrifice him in hopes that he grows up well, not in a dirty apartment. God bless you. (Owens, 1987)

This poigant note was found inside the blanket of a newborn baby, left by his newborn mother. The first act of her new existence she experienced as sacrifice. Still, the media and the public at large apparently consider this child "abandoned."

The newspaper accounts report to us that the authorities are seeking the abandoned baby's mom. These authorities claim they are concerned for the health and welfare of the mother, and yet, at the same time, there is talk of which "criminal charges" may apply. The only criminal charge that might apply is abandonment, but this probably doesn't fit the circumstances, at least so far as the authorities are concerned.

Langeveld (1971) says that a mother is by nature inseparably the mother of her child. She runs away from herself, she runs from nature and the essence of womanhood if she abandons her child. But did Phillip Thomas's mother abandon her child? To what great recess does a woman run when she makes the decision to give her child to adoption? Is she a lesser woman because of it?

Abandon as we have come to know the word, has many nuances. One definition is to give up with the intent of never again claiming a right or interest in. Certainly the mother who gives up her child does not wish to break the unwritten, unspoken code: once the decision has been made there shall be no imposing on the child's happiness; but the mother does not, cannot lose interest in the child. She will simply not interfere.

Another definition of abandon is to give up to the control or influence of another person or agent. Here we do not have the connotation that the person being "left" will be open to physical danger. Still another definition offers abandon as a thorough yielding to natural impulses. Is this what the mother who knows she must give her baby away is doing-thoroughly yielding to her natural impulses, this same nature that makes her, inseparably, a mother? 


\section{Others not Mothers: Experts, Agencies, Newspapers, and so Forth}

She is, of course, surrounded by experts who would have kept that child no matter what. There is disgust in the voice of one who thought the mother should have at least gone to an adoption agency and attended to the legalities and formalities which are "properly" associated with this heart-wrenching and much misunderstood decision making process. There is relief in the voice of another who was so glad that the couple who found the baby would not be able to adopt him; after all, if the mother knew where the baby was she could come back at any time and claim him. There is disapproval of this apparently selfless act because what it really smacks of is irresponsibility: "These young kids, they want the sex but not the consequences."

The head of a group for unwed mothers said the mother probably felt isolated and unaware of the many agencies that could help her. (It is assumed, of course, that the young woman is unmarried.) And what of those agencies located on the top floors of shiny glass buildings, or near police stations, or in the business district, or in an area of town where you're afraid to walk alone? Are these the "many agencies" there to help the young mother? Is this the accessible? As soon as you walk in such a place you are exposed, vulnerable, open to curious looks and knowing whispers, and endless, painful paper work. Knowing that an agency is there does not make it therefore inviting. Indeed, any prior knowledge of the interviews and attendant paper work make "abandonment" a viable, perhaps more humane, option. One wonders whether the head of the group is, or was, an unwed mother herself, has given birth to a child, has decided to give her child to others to raise and love, or if she is yet another vicarious expert in the field of motherhood-unwed or otherwise.

What the "experts," and authorities, and humanitarians may not have taken into account is their own alarming lack of experience. Insofar as adoption or social service agencies purport to "be there" for the mother who decides to entrust the care of her baby to others, being physically or materially present and "being there" are two different things entirely. "Being there" is the true presence of a friend or else someone who cares for you so that there is the chance to share, to grow, to see, to be with and for another, unconditionally, gently.

We return to the present_- "Police seek abandoned baby's mom"such a reassurance for a woman who managed, not 12 hours after one delivery, again to deliver her child to the possibility of health and happiness that she did not feel equipped to supply. One newspaper editorial tells us that, according to the experts, surrendering a child so he'll have the best life possible is incredibly mature. (In some ways, we are told, putting a baby up for adoption is harder to deal with than is death.) 
Tanya, 16, knows the agony Phillip's mother must feel. She changed her mind several times before letting her infant son be adopted, two weeks after he was born. "It's hard, especially when you have to sign the papers. I understand how she feels-it hurts just handing over your baby." The child's father had left, and the Grade 10 student knew she couldn't care for her baby properly and fulfill her dream of attending college. Tanya knows the family who adopted him, and she hopes he'll want to see her when he's old enough. For now, she's happy she has had the support of friends and family.

Perhaps we can now reconsider the various responses of individuals to the newspaper's dramatic portrayal of the abandoned child. There were the experts with their facile assurance of (and supreme confidence in) an adoption agency, but we have come to a new realization that forms, questions, and the quest for certainty can make the whole experience painful and, worst of all, routine. There was the expression of relief that the mother would never know of the new parents and hence not be in a position to reclaim her child. But in this view there is the assumption that absent moms are out on a retrieval mission; that they want to impose themselves on, or interfere in, the lives that the children and their adopting parents will have made. Tanya just wants to know how her child is doing, that's all.

"Well, honey, you should have thought about that when you gave him up." She shakes her head and insists "that's all I did think about!" Statements like this have equal ranking with "are you sure?" Damn it, of course you're not sure! You are filled with uncertainty. But you are sure of one thing: You want the best for your baby. So you lie, sort of ... you say, "Yes, I'm sure" when you know, deep down inside that all you're really sure of is that you love this child.

\section{Hello, Baby. Who Are You and What Are You Doing to Me?}

Let us retrace steps for a moment. "Living with an absent child" is at the heart of this reflection, and from this flows noticing, thoughtfulness, susceptibility; but before there was absence there had to be presence. One cannot miss what one has never had. Missing and absence presuppose a previous relation. The intensity of that relation pronounces itself and relives itself in the living with the missing, and the enduring absent presence.

Attending to the previous relation lays the ground for making some sense of "absent presence." Perhaps a mother can tell it best:

A little over six years ago I decided to give up my baby-my sonfor adoption. It was the hardest and the easiest thing I've ever done. If I were to put a time on the gut realization that I could not keep him, it was when my doctor told me that, yes, I was indeed pregnant. I knew I was pregnant before she told me, but the definitive medical confirmation made the continuation of my private, almost hopeful dream of life with my new baby impossible. Hard facts, after all, demand action, but I was sad, a little-my son 
and I were getting to know each other, I felt him in me from his very beginning.

Phyllis Chesler (1979) asks her unborn son: "Did your existence begin when the urine test confirmed it? Or was it before that, when I sensed your presence in me?" Who can know what passes between mother and child in their unique togetherness except the mother and child? It is indeed important to share joy with special others, but when the external future is a question, the internal present is a relationship that is fiercely, jealously guarded.

The afternoon in the doctor's office was an incredible, overwhelming experience for me. I discovered later, that being overwhelmed, being happy and sad all at once was fairly typical (insofar as new life within can be typical) of the feelings that many new mothers experience. There is something terrifying, poignant, and wonderful about someone else telling you you're pregnant.

"Well, my dear, those are definitely pregnant breasts"-spoken with the comforting matter-of-factness that is characteristic of physicians who have seen many such pregnant breasts. What is there to say now? She is lying on her back, naked, under a crunchy white sheet, feet in cold, black and chrome stirrups. She shivers slightly, gratefully; the air conditioning sends a cool breeze across her damp forehead, her sweat from endless stairs and a steam bath of a waiting room is evaporating; her body can feel the expanse of space not 160 offered by clothing that barely fits anymore. Her head aches from thinking, from worrying, from wondering, from sheer fatigue; her limbs are motionless, but her breathing is easy and her body is relaxed on a bed that was definitely not designed for rest, relaxation, or peace of mind. Is this the relief of coming to know what you've really already known?

Okay. So now the diagnosis has confirmed what the body has been insisting these past few months. Next are megadoses of iron, frequent weigh-ins, ultrasound, and finally a reason for being so sick and tired and scared and confused-pregnancy: new life within. The real panic can now begin.

She is not being deliberately flippant. She is simply neither prepared nor equipped for the onslaught and magnitude of the feelings which the physician's simple pronouncement has instigated. More than this: she herself is more than aware of her unpreparedness. How can she care for this baby? How can she give it the life, the love it deserves? But how can she part with a life that is intertwined and joined with her own? It is not simply a matter of wanting or not wanting.

I wanted my baby, but I also wanted the best for him. Isn't that part of being a mother-wanting the best for your child? When I first felt his presence in me, I wanted to keep him this close forever; there was no way I could have decided to give him up, at that point. 
I did not decide to give up my child until the last possible moment we could be alone together, unknown to others. I made my decision that afternoon in the doctor's office, under a crisp white sheet, feeling the pain of knowing and the pain of parting oozing in and out of me all at once.

\section{Be Still and Know}

"We've decided that we aren't going to keep the baby." How one statement can encompass so many lives, so much anguish, so much uncertainty, so much conviction. What to think about? What's best for me, what's best for him, for us?

The doctor said, "If you're sure about this, we must let the hospital know. And, of course, you must see a social worker; there's an awful lot of paper work to do with situations like this." The doctor's eyes are avoiding her patient's eyes; there is annoyance, distaste, the knitted brows of someone trying too hard not to be judgmental and not to show puzzlement. It's not professional. Neither, though, is clinical detachment.

The doctor offers an address. "There are other girls there in similar circumstances." Girls in similar circumstances ... what might that mean? Girls who are pregnant? Girls who are confused, scared, uncertain, unprepared? Girls who are thinking about giving up their babies? "Girls" decide to give up their babies, women do not.

All the same, there can be no more solemn or solitary act than the deciding to give a child to others for safekeeping, for nurturing, for cherishing. Perhaps more than anything, the mother commits to her natural instincts as "mother": the care of her child, the welfare of her child even above that of herself.

How is it that babies can carry such divine mystery even as they are carried themselves by such fragile vessels? How does the "transfer" take place? When does the mother become mysterious, too? Perhaps when, in spite of herself (or because of herself?), she begins to talk with and listen to her tiny messenger, her life giving gift-perhaps, then, "transform" is a better, more proper word than transfer.

\section{Watching, Waiting, Wondering}

I remember my experience in group counseling. The woman who headed the group was a religious sister, a warm and caring woman, but one hardly in a position to say (or know) what we mothers in various stages of abdominal distension "probably felt" as we sat and talked about the most important decisions of our lives. We sit on easy chairs, sofas-the furniture selected and arranged to resemble as much as possible, a cozy living room in a house (home?) where meaningful and compassionate conversations take place frequently. We were drawn together, perfect strangers, by the power of what we feel moving in our bellies; there was the need to speak, to be heard, to be listened to. There were the ongoing, often 
fruitless, attempts to sit normally, or even still for a few moments. I remember the typewriter tapping in the office at the end of the hall - always there were forms to be attended to. The toilet flushed with the consistency and constancy of a roomful of pregnant women, the chairs groaned and squeaked in an effort to conform themselves to bodies seeking any comfortable position. I remember the questions which were gentle and real: "Are you keeping yours?" "Oh, yes. I'm going to marry the father, it's for the best . . "Or, "Well, no, I think it's best to give mine up," "My parents think I should..." All this was being spoken with a mixture of torment and relief, wondering and fear. We had found our way to this group through referral, parental pressure, but perhaps ultimately from a need to reveal our uncertainty and caring to others who felt the same. We cared so much; we needed to be with others who knew this, but knew it because they felt that same ache, that same terribly human feeling of caring for and about another-one's childjust as much. There was, too, a strange sense of the tragi-comic. We joked about things that might not have been considered very funny outside this room. It was release, it was sharing, it was consolation of sorts.

But there was nothing about the place that was authentic. It was like so many imitation homes, or pretend caring centers-founded on transient, somewhat puzzled sympathy. There was nothing consoling or welcoming about this separate place; only the peoplethe pregnant people-in it made it the quiet haven that it tried so hard to be.

There is not much dignity attached to your decision; and there is not much privacy, either. You are an open book. Everyone knows about you and your decision. You are usually treated quite differently from "real mothers" by hospital personnel, and so is your baby-at least that's how my baby and I were treated.

From admission to release I was treated with cold efficiency, as if I had a disease that anyone could catch if he got close enough. I was fascinating, a puzzle - observed by the professionals with a strange mixture of bewilderment and disdain. The other mothers, though, treated me like one of them. I do not know if they knew that I was not keeping my child, but I do know that they told me not to mind those heartless doctors, and they included me as a mother, which, after all, I was. I am.

What makes a mother? Is it childbirth? Is it bearing the child, nourishing and sustaining him for his first nine months? Is it raising him, spending his growing years with him? When do women become mothers? Does something magical happen during or after childbirth? Is this the forging, the test by fire, or do mothers become themselves under the gentle pedagogy of the tiny teachers who make them feel too much, too soon? Are we mothers when we begin to care, to wonder, when we realize we are moved by a child we can't 
even see? When does motherhood begin, and when does it end-or does it have a beginning and an end? Is it time bound?

\section{Being Born}

I was aware that I had to remember everything. . . All that we had done and were doing together during his birth, "our" birth, really, was turning into memory in my mind, my heart, my sense. After all, I knew that very soon I was never going to see him again. And, then, I had to ask for him. I had to ask to look at my child; it was "a look that violated common courtesy" (Grumet, 1983, p. 47). Why did I want to look at my child when I knew it was a look of impossible opportunity? We had a momentary meeting, a cheat, really, because no relation could come of it, and yet, perhaps there was something. There is something. The look said "you're mine forever," wistfully, from mother to baby but, more significantly from baby to mother, and it was absolutely correct. I am his forever.

Settled in his mother's arms, he stopped squirming and his clenched eyes opened and fastened on her. Not yet ten minutes old, he made eye contact with her, and an unmistakable look of recognition crossed his face. They studied each other carefully. He knew her, she knew him. (Kagan, 1986, pp. 48-50)

He was within me; he was inside me, enclosed; the walls of my flesh housed him. He was, and so he is part of my inner thought, my disposition, my character. He plays a part in my being thoughtful, and in my reflecting. We named each other our first new names: baby-son; mother. Who else knows me as mother? Yet, in all properness, another mother is known as mother, and knows him as son, undoubtedly much better than I do, and perhaps ever could.

\section{The Shape of Things to Come}

I was not told if or when I could see my son while we were in hospital together. Certainly, there was to be no breast feeding: contact is discouraged. One compassionate social worker finally told me I could see him, during our stay in hospital, anytime I wanted. So I sought him out, only to discover him in a separate nursery, away from the other babies. There is the assumption that because you don't want to keep your baby, you don't want him, period; therefore, you don't want to spend time with your newborn child; or, it's better that you don't spend too much time with the baby so you don't become too attached. I've got news for them: They're too late! The irrevocable bonding has already taken place during the relationship within, during the being born together.

We are reborn even as we participate in each act of being fully human, as we give ourselves to our humanness, our being. Just so, the mother who gives her child does not interfere in the new freedom that has been created by her freedom to choose. There are times 
when a mother of an absent child may shake her fist at the sky and ask, "Why, why wasn't I ready then?" and "Why (how?), did I know I wasn't?" and "Why did I use my God-given freedom to free my own child from me even though I am his captive for ever and ever?" But, thankfully, the fist_-and the body-does stop shaking and she realizes that she has become privy to a relationship greater than she could have known or imagined; she, by becoming less, has created more.

\section{Good-bye}

Once out of the hospital the baby stays in a foster home for several months. When it is clear that his parents do not want him, he is put up for adoption and the parents then lose all rights to the infant. These are the rules.

It's hard, especially when you have to sign the papers. And before the papers are signed there are personal history forms on the mother and father and three or four interviews which always culminate in the burning question: Are you sure?-and all this before the baby is born. After the birth, there are more interviews, paper work, and finally "signing the papers"-but there is no closure.

I remember leaving him: I am lingering at the window of his nursery watching him move in his sleep. My fingers are on the glass and I whisper "good-bye, baby" and I'm crying very quietly and feeling an ache-not only in my throat but in my heart, in my bones, that will be there, more or less intensely, for as long as I live. No one prepared me for this missing, but I caught a glimpse of it that afternoon in our last moments together.

There is contradiction, yes. There is "logical incongruity"; it is proper for my son to have the life he deserves, yet my unending wondering about him can be, must be, no less proper. I'm his mother-mothers wonder at and about their children ... don't they?

So here we are, in the here and now. We see a young mother who has given up her newly born for adoption in the enduring conviction that she has done the right thing, the best thing for the child; and yet now she must live with the enduring presence of her child's absence.

She gave, but is unable to forget; her son belongs to other parents now: He is theirs in a way that he can never be hers. Yet he is hers in a way that he can never be theirs. This is the fundamental and apparently unresolvable contradiction of the meaning of adoption for the "first" mother.

It is my privilege, and duty, almost, to give testimony not only on behalf of the mother and woman that I was, but also on behalf of the mother and woman that I am and am becoming. Indeed, this reflection is as much a tribute to the beautiful, loving, hopeful present as it is a memoir, a delicate disclosure and revelation of a mother being born, and of a child being known, loved, cherished, and "lived with" in a way that defies description or expression. 


\section{Whither Thou Goest...}

What is it like to live with an absent child? Perhaps more than anything else, it is one-sided. The bond and the bonding are felt by one person. The mother carries this precious being and delivers him to a relationship that she creates with her decision. At a time when power would seem to be a dominant factor, all that one feels is humility in the face of something much more beautiful and powerful: human life.

The short time that mother and baby have with each other is nonetheless long enough and strong enough to forge a togetherness that cannot be forgotten, regretted, or denied, a togetherness that is remembered, relived, and lived with excruciating fondness and tenderness. She is his mother, an unalterable, irrefutable, recurring, unending awareness, wondering, missing. How strange that one can miss utterly someone one has only known briefly. It was and is the quality of the knowing that makes the missing and the absence so intense.

Living with an absent child is the feeling of irrevocable connectedness superimposed on the reality of undeniable separateness. It is constant joy, a constant question, a constant susceptibility. It is the knowledge and acceptance of the inevitable daily reminders of that which was and remains precious, yet necessarily unshared, unrealized, of that which could have been.

My living with my absent child is not regret or guilt. It is a constant wondering at and wondering about. It is an ongoing, unending wistful kind of sad longing that is nonetheless very pure. I could not and cannot be his parent, but I am and always will be his mother. I do not live with him in the sense that we share a home, space, or time together. We are not a presence in each other's lives; he is, however, a very real presence in my life. We do not have nor can we develop a relationship. He does not know he is absent from me any more than he knows he is a presence in my life. He is present in his own surroundings, separated from me; he is not here, physically, actually, in my surroundings. He is preoccupied with and occupied in his own life. It is as it should be.

\section{Words}

My son is not "in view"-he is quite definitely "away." I have no idea what he looks like, how tall he is, the color of his hair or eyes, how the light dances in his eyes or brings out the shades of darkness and lightness in his hair; I cannot see his facial expressions, the look in his eyes, the way he tilts his head, the beautiful, unrestrained movement of his young, growing limbs-he is not "in view"; he is quite definitely "away." Yet his presence is very definitely here, with me, in me-not in a visible, concrete form, but as 
something felt, and felt quite powerfully. He is "virtually" present: being such in essence or effect though not "formally" recognized or admitted.

Essence has its beginning in the phrase in esse: in actual as opposed to potential being. This phrase exemplifies the Latin esse: to be. It is linked with etymology and sooth - that which is, exists: that which exists is true. He is virtually "in actual being" but he is actually absent. His absence is a fact, a reality. His presence is a truth. It is his essence-his individual, real or ultimate nature as opposed to his existence-that is present.

Ultimately, he is my son, I am his mother -yet he knows nothing of our relationship, unless somewhere hidden in his memories are the conversations we had as he rolled and turned inside me, or the feel of my hand on his head as he slept against my chest. He took my breath away. Existentially, he is their son, and I am happy for and proud of the love they know together. It is as it should be-still, he evokes such wonder and reverence in me; still, he takes my breath away.

I live with my absent child. I live with the presence of my absent son. I do not "live with" my child-he is not in my cure, yet he and I are participants in an arrangement that I determined, and that I actively participate in every day. It is a strange ironic contradiction that only in his absence can he be a participant in this "ar166 rangement" of ours, of mine.

Missing is a consequence of absence. Because he is "away," I miss him terribly, even though he is not actually "mine" to miss. While I retain great conviction in the properness of my decision to not keep him, the missing and the wondering are consequences that, while anticipated, are still quite profound. Strange how such deep conviction and such keen awareness of absence can coexist.

Living with an absent child is not the same as the experience of "adopting out": $A d$, Latin, meaning toward or in the direction of, "opting out," choosing not to participate in something. This does not happen. The "choice" is not one of nonparticipation. The mother of the child is the child's mother for as long as she lives. She cannot choose to not participate. She can pretend that she was not touched or moved, but she is "involved" even though her child is absent. She participates in the reality of the "missed relationship," the "nonchance" to touch one another's lives, while at the same time realizing that her child has touched and changed her forever.

\section{Absence}

The "what if"s can rule an existence. "What if" is the uncertainty that may accompany a pressured decision, a panic decision, a nondecision, or a decision made against irrefutable knowing. The only expert is the mother. She alone knows. But decision is not absence: "what if" is not absence. All the anticipation and personal, 
private resolve does not prepare the mother for the missing, the wondering, the absence that does not end.

Knowing that the "right thing was done" does not always console the absence, either. The living with absence is chronic: It is always present or encountered. It is marked by long duration and frequent recurrence. The living with absence is a steady, accepting state. It is not penance. It is an addition, a companion: welcome, essential, a part that belongs there, now. It is the giving of oneself to remembrance, to feeling, to caring, to loving. It is the daily awareness of the child's absent presence as a gift; it is an opportunity to be reflective; to be there for the world as it presents itself in all its gloom and glory. Living with an absent child is antinomy, it is also serendipity: the faculty of finding valuable or agreeable things not sought for.

Absence can be more and less than ongoing. It can be "acute." It makes itself known with great sharpness and severity at those times when the presence of other things makes his absence so keenly, intensely felt.

There are "triggers" or "initiators" or "reminders" that let me know he isn't here. (They do not scold or admonish: there is no sense of "you fool, you made a big mistake!") These "reminders" are unpredictable, endless, unexplainable, but very real-and I am susceptible to them because living with his absence is not a coat that I put on, it is a heart that beats inside mine. I attend to these triggers, voluntarily because he and I deserve to feel this much, and involuntarily because I cannot help myself, nor do I wish to stop my myself, from being seriously, urgently, utterly involved as an absent mother.

\section{Reminders: Church, Baby Clothes, Tummy-Then and Now}

All the cute babies (are there any other kind?) go to church on Sundays. I am surrounded by soft, furry heads, huge, gleeful eyes, curious, utterly incredulous expressions, little fists and feet that move in the most wonderful ways. I can feel the way they are being held. I can feel that small head resting in my hand, I can feel that tiny body cradled in my arm, leaning on my chest, sighing contentedly in sleep. I can feel that look of recognition between the parent and child, the connection, that feeling of complete and utter love, that touch-natural, unlearned yet constantly discovering and watchful, ever learning from and wondering, marvelling at this miracle that we-they were able to keep and love.

Baby clothes can be a real trial for mothers who live with an absent child. It is not so bad in stores. There, they can be observed with the detachment of a prepared action plan. But a friend can pull a sleeper or booties out of a shopping bag (they are a gift for so-andso) and I can feel my face (and everything else) soften. I can feel a smile and at the same time a strange ache in my throat. I get an inside quiet that only I know; that's when I feel him. That's when I feel his absence. 
I lie in bed in the dark-and I remember how he lived inside me. I am so flat now, concave even, as I lie on my back, but I remember the incredible feeling of properness and peace that used to fill me when I put my hand over him and felt him move, felt him grow still, felt him sleep. He pulled me to himself; he pulls me still. I am drawn to him even as I gathered him to me in the quiet night as we held each other.

I sat on the bus today and watched a beautiful, bundled, wide eyed, puffy-cheeked baby (girl, I think) fall softly, gently asleep, so vulnerable, so trusting, so protected, and I felt everything inside me crumbling. Times like this my bones turn to water and I feel so weak, so yielding, yet so strong, so willing to care. I feel that warm releasing, private weeping, and the tears pour down behind my eyes; I feel the incongruity of inexpressible joy and longing all at once. And I take a breath and feel silent wonder as I gaze at this child until she is carried off the bus.

This is something of what it's like to live with an absent child: Too much feeling for, too much missing of, too much wondering about a child I'll never know, but one I live with every day.

I can only conjecture how he might be, how he might look, now. There is the constant reality of 6-year-old boys, and I am much more mindful of children since he touched me. I am watchful. Their movement and expression rivet me, somtimes-not just babies, al168 though they seem to pull the hardest (I knew him only as a baby). It's not so much regret because I "lost" someone or "missed" something, it's more a question of "mothering." I never mothered my child and I wonder if I'll ever get the chance to try mothering-at all! (it's hard to be the mother of a 6-year-old when I haven't mothered the infant).

I remain preoccupied with mothering my absent son, and this living with the absent child is not time-bound; his age does not sequence chronologically. Today he may be two-tomorrow, six. He may come running in from school or play, skin flushed, eyes sparkling, words tumbling; he may nestle his soft head against my chest, he may hold my hand as we cross the street; he may touch my face as I lean close and stare at him in his crib.

These are images that I have not lived, but do live. I cannot know him except in these images, these encounters, these noticings through others, but I can and will always feel him rolling and turning inside me, and I will not forget the look that passed between us-mother and son.

So I live this mothering whenever and wherever I witness it, and whenever and wherever I encounter the reminders-on the bus, in church, in the consoling darkness. 
We remain connected, bonded, thanks to "recognition," susceptibility, thoughtfulness, and, ultimately, thankfulness. I am thankful for the gift of my son's life, for the joy he has brought to my life, and to other lives, for the privilege of knowing him, and the private tenderness of living with him, my absent child, every day. I would not be who I am without him as part of my within... proper, somehow, that he lives within me still where we first knew each other, and where I came to know and love in a way that remains unforgettable, intimate, and deep.

Does a mother forget her baby? Or a woman the child within her womb? She can never forget her own. Memory is indeed becoming mindful of one's own stake in things.

\section{Wanting to Know; Going On}

Lize Stilma (1984) has written a poem, "Mary," about a woman considered "crazy" by the people in her neighborhood. These "neighbors" had become desensitized to Mary's calling in the night. They had even ceased to feel sorry for her.

Mary calls into the night for her daughter, a daughter who was taken away by well-meaning authorities, based on their assessment of Mary as an unfit mother. This woman suffers incredible anguish, until one day a stranger visits her with news of her daughter. The stranger reports that "Salina" was happy and never wanted for anything. He does go on to say that although Salina lives no more, she died without pain. Mary's 20 years of anguished pleading and wanting, needing to know, reached a sort of calming climax with the stranger's news of her daughter. The poem finished with the neighbors' wonderment at the latest development in Mary's "insanity": "she doesn't yell anymore ... she waves at the clouds and laughs!"

I shed warm, secret tears when I read this poem. This is the "head down so no one will see" variety of weeping, and, yet, why tears? Sorrow? Not really. They were tears of relation, tears of recognition, tears of shared anguish, tears of joy for. a mother who now knows what I would very much like to know. Rejoice and be glad, Mary.

It is the "not knowing" which is most painful at times. All the authorities will tell you: It's better not to know; but then, how do they know?

Having a child taken is a different kind of torment from giving up the privilege of mothering the child through a considered or coerced decision-but the not knowing is not joy, nor gift, nor comfort. It is consequence of knowing too well.

We are never lonely by ourselves-only in the absence of another. Loneliness is not a solitary experience. It is, rather, the experiencing of sharing, time, space, and body with an absent other, but more than "any" other: with a special other. An other who possesses and inhabits, an other whose touch lingers and disturbs and repairs and transforms. 
Mary's wall of loneliness came down when she was finally without an uncertain Salina. She needed to hear: "your child is fine." Although she never mothered her child, it was good to know the mothering was done. All her suffering, her twilight anguish was worth the knowing that her child did not, does not, suffer.

"The act of experience must in some measure determine itself. Only thus can it be responsible in an ethically intelligible way for itself or for the overt actions to which it leads" (Cobb \& Tracy, 1983, pp. 39-56). Is removing oneself from a context an act of selflessness or an act of irresponsibility? By its very existence the child deserves a response, indeed, provokes a response. Is giving the child to unknown others a response, or is it merely selfishness? What kind of things should a mother know about these strangers? Should she know anything?

Making the decision involves coming to an ability to trust. You want to give your child to people who can care for and about him, and yes, you do lose all rights to the child in terms of "ownership" or parenting in person, but you cannot stop the urge, the instinct of a parent to remember, to want to remember, to wonder how the child is, how he is doing, to simply wonder at this wonderful little being who is touching and changing so many lives.

"I will never forget you, my people.

I have carved you on the palm of my hand.

I will never forget you, I will not leave you orphaned.

I will never forget my own.

Does a mother forget her baby?

Or a woman, the child within her womb?

Yet, even if these forget, I will never forget my own." (Isaiah 49:14-16)

Why is Isaiah saying this to the people of God and, inevitably, to us? The people of Israel had "forgotten" God, their father, but He had not forgotten them. The parent remembers. Isaiah reminds us that the mother is the most unlikely person to ever forget her child. Indeed, some yet to be published research suggests that sperm donations have emotional consequences for many people. The research suggests that sperm donors do not forget. Rather, in later years they experience various emotional reactions to what they were led to believe was a simple process. The creation of new life has lifelong consequences (Ensminger, 1987). If such a detached process can produce the inability to forget, imagine the consequences for the most absolute attaching there is: that of feeling life begin inside you, carrying this life, feeding and sustaining this life, loving and knowing this life.

Carrying the child shapes the mother and delivers to her the inability to forget. Perhaps it might be a good thing to be able to forget, but the mother cannot. Absent moms are mothers moving forward, 
ahead of themselves for their children. They are teachers, they are taught. They are messengers, deliverers; they receive messages, and are delivered. They are confusion, yet they know peace, they know loneliness, but they also know connectedness. They know the conviction of giving, yet they feel wonder at the hold their child has on them.

Isaiah assures the people that it is as unlikely for God to forget them as it is for a mother to forget her baby. God has carved us on the palm of his hand. Just so, the baby leaves his mark forever on the mother; he is imprinted on her; having carried him within herself, her mind, and soul, and self cannot forget him.

Isaiah is also asking the people of God to have faith. What does it mean to have faith?

I don't know all that faith means. I do know that I had to have and do have faith in these strangers who are the parents of my child. I think that living with my child's absent presence has allowed me to feel a sense of hope as well... although I don't really know all that hope is, either. Today I feel my child's presence as much as I ever did, and he has helped me grow up in many ways. I feel a readiness, now, in a loving relationship that could bear a child, raise a child, love a child, leave her unwounded, questioning, wondering at, and not fearful of uncertainty. I can carry my son with me everywhere, and I know that my decision to not keep him has not made me suspect or lacking as a woman, or as a mother. I was my own harshest judge, I'm afraid. I feel strong when I think of my son, of what he has taught me, of what our experience together has done to me, and for me, and in me; I feel strong in our absent togetherness and I often think of all that we, and I, could bring to another child. I think I have strength enough, humility enough, and love enough to give to a child, now. I'm really sort of hoping it's going to happen.

\section{References}

Chesler, P. (1979). With child. New York: Harper \& Row.

Cobb, J.B. Jr., \& Tracy, D. (1983). Talking about God. New York: Seabury Press.

Ensminger, R.O. (1987, January 28). Think before being sperm donor. The Edmonton Journal, p. A5.

Grumet, M. (1983). My face is thine eye, thine in mine appears: The look of parenting and pedagogy. Phenomenology + Pedagogy, 1(1), 45-58.

Kagan, D. (1986, December). Father love. New Woman, pp. 48-50.

Kent, G. (1987, January 23). Police seek abandoned baby's mom. The Edmonton Journal, p. 1. 
Langeveld, M.J. (1971). Erziehungskunde und wirklichkeet (M. van Manen \& P. Mueller, Trans.). Braunschwag: G. Westman Verlag.

Owens, G. (1987, January 22). Newborn left on doorstep. The Edmonton Journal, p. 1.

Stilma, L. (1984). Portraits. Phenomenology + Pedagogy, 2(3), 295-303. 